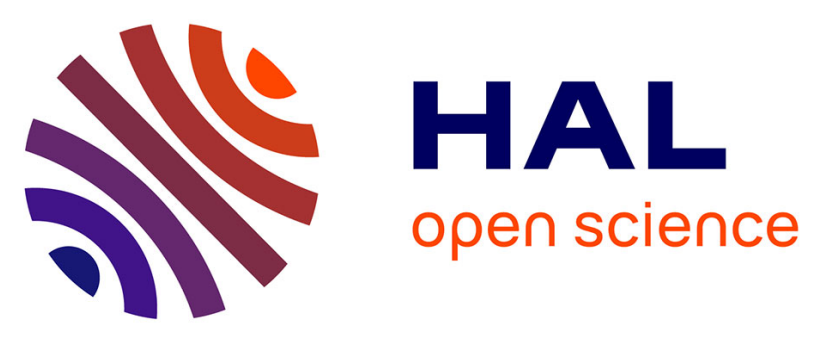

\title{
An in vitro model to assess the peripheral vestibulotoxicity of aromatic solvents Running title: In vitro screening of aromatic solvent vestibulotoxicity
} V. Tallandier, M. Chalansonnet, L. Merlen, S. Boucard, Aline Thomas, P. Campo, B. Pouyatos

\section{To cite this version:}

V. Tallandier, M. Chalansonnet, L. Merlen, S. Boucard, Aline Thomas, et al.. An in vitro model to assess the peripheral vestibulotoxicity of aromatic solvents Running title: In vitro screening of aromatic solvent vestibulotoxicity. NeuroToxicology, 2021, 10.1016/j.neuro.2021.03.002 . hal-03176306

\section{HAL Id: hal-03176306 https://hal.science/hal-03176306}

Submitted on 22 Mar 2021

HAL is a multi-disciplinary open access archive for the deposit and dissemination of scientific research documents, whether they are published or not. The documents may come from teaching and research institutions in France or abroad, or from public or private research centers.
L'archive ouverte pluridisciplinaire HAL, est destinée au dépôt et à la diffusion de documents scientifiques de niveau recherche, publiés ou non, émanant des établissements d'enseignement et de recherche français ou étrangers, des laboratoires publics ou privés.

$$
\text { Copyright }
$$




\title{
An in vitro model to assess the peripheral vestibulotoxicity of aromatic solvents
}

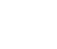

Tallandier V. ${ }^{1,2}$, Chalansonnet M. ${ }^{*}$, Merlen L. ${ }^{1}$, Boucard S. ${ }^{1}$, Thomas A. ${ }^{1}$, Campo P. ${ }^{1,2}$, Pouyatos B. ${ }^{1}$

9

\author{
${ }^{1}$ Institut National de Recherche et de Sécurité. Rue du Morvan. CS 60027 . F-54519 \\ Vandœuvre Cedex. France
}

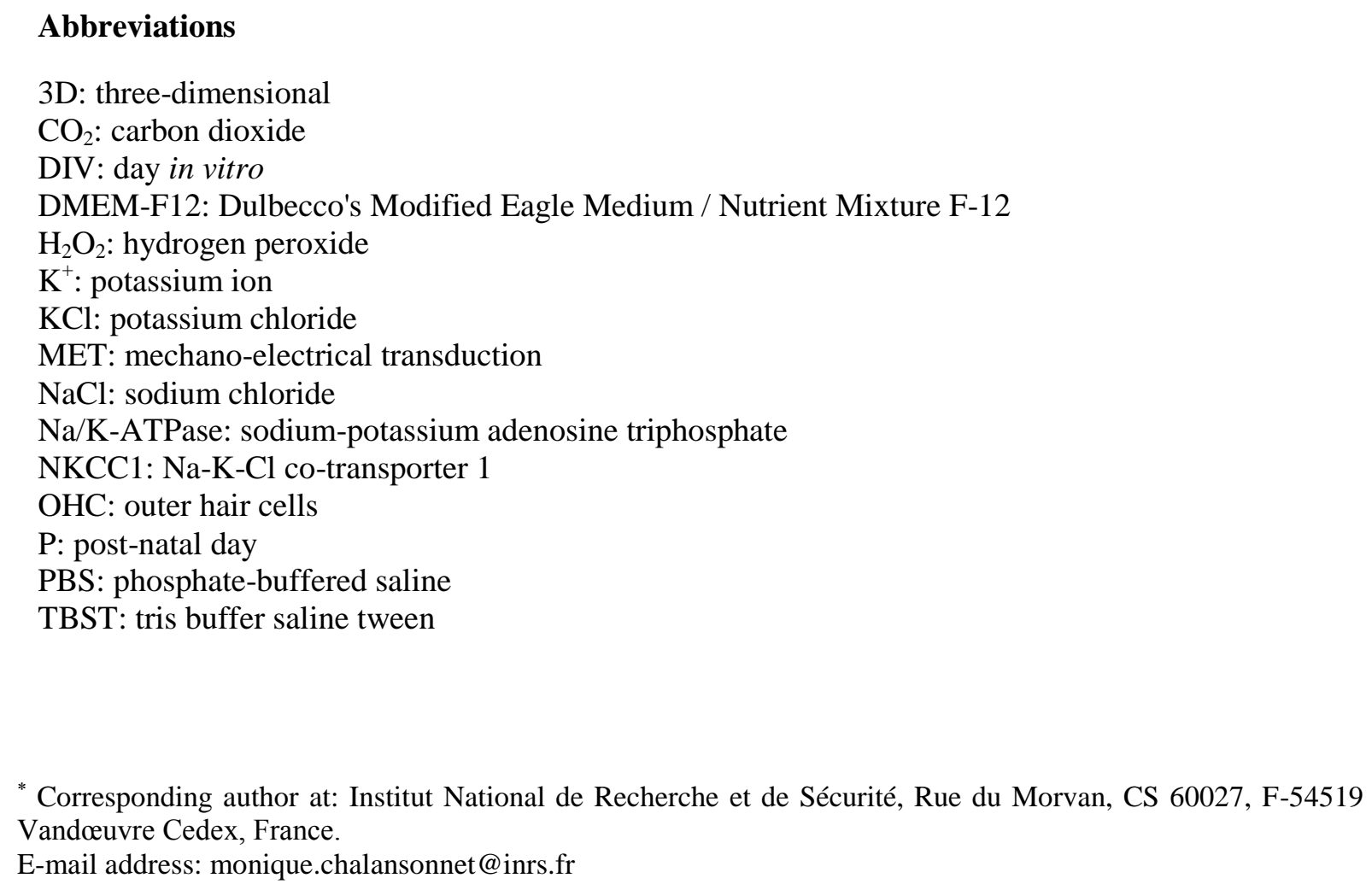




\section{Highlights:}

60

61

62
- Endolymphatic $\mathrm{K}^{+}$levels in cultured utricles reflect solvent vestibular toxicity

- $O$-xylene, ethylbenzene and styrene decrease $\mathrm{K}^{+}$concentration

- No effect on $\mathrm{K}^{+}$concentration following exposure to $p$-xylene, $m$-xylene or toluene

- Cochleotoxic solvents are not necessarily vestibulotoxic, and vice versa

2

3

4

45

46

47

48

9

50

51

2

53

54

55

56

57

58

59

60

61




\section{Abstract:}

Epidemiological and experimental studies indicate that a number of aromatic solvents widely used in the industry can affect hearing and balance following chronic exposure. Animal studies demonstrated that long-term exposure to aromatic solvents directly damages the auditory receptor within the inner ear: the cochlea. However, no information is available on their effect on the vestibular receptor, which shares many structural features with the cochlea and is also localized in inner ear. The aim of this study was to use an in vitro approach to assess and compare the vestibular toxicity of different aromatic solvents (toluene, ethylbenzene, styrene and ortho-, meta-, para-xylene), all of which have well known cochleotoxic properties. We used a three-dimensional culture model of rat utricles ("cysts") with preserved functional sensory and secretory epithelia, and containing a potassium-rich $\left(\mathrm{K}^{+}\right)$endolymph-like fluid for this study. Variations in $\mathrm{K}^{+}$concentrations in this model were considered as biomarkers of toxicity of the substances tested. After $72 \mathrm{~h}$ exposure, $o$-xylene, ethylbenzene and styrene decreased the $\mathrm{K}^{+}$concentration by $78 \%, 37 \%$ and $28 \%$, respectively. $O$-xylene and styrene both caused histopathological alterations in secretory and sensory epithelial areas after $72 \mathrm{~h}$ exposure, whereas no anomalies were observed in ethylbenzene-exposed samples.

These in vitro results suggest that some widely used aromatic solvents might have vestibulotoxic properties ( $o$-xylene, styrene and ethylbenzene), whereas others may not ( $p$ xylene, $m$-xylene, toluene). Our results also indicate that variations in endolymphatic $\mathrm{K}^{+}$ concentration may be a more sensitive marker of vestibular toxicity than histopathological events. Finally, this study suggests that cochleotoxic solvents might not be necessarily vestibulotoxic, and vice versa.

\section{Keywords: aromatic solvents, vestibular explants, endolymph, potassium}


Aromatic solvents are used extensively in industry for many manufacturing processes across a broad spectrum of applications such as printing inks, paints, varnishes, adhesives, coating, cosmetics, cleaning and degreasing, pharmaceuticals, plastics, and chemical manufacture. Because of their high volatility, aromatic solvents are mainly absorbed into the blood through the respiratory tract (Dick, 2006). The deleterious effects of aromatic solvents on hearing have been known (Hodgkinson and Prasher, 2006), and raised auditory thresholds have been reported in workers exposed to aromatic solvents in the workplace (Sułkowski et al., 2002; Unlu et al., 2014; Vyskocil et al., 2012). For this reason, the cochleotoxic effects of aromatic solvents and their underlying mechanisms have been extensively studied in laboratory animals. Rats chronically exposed to vapors of solvents, such as styrene, toluene, ethylbenzene or $p$-xylene, display permanent hearing deficits and loss of outer hair cells (OHC) (Cappaert et al., 2000; Loquet et al., 1999; Maguin et al., 2006). Although the precise mechanisms leading to $\mathrm{OHC}$ death following exposure to aromatic solvents is not fully understood, it has been hypothesized that aromatic solvents reach OHCs through tissue contamination rather than contamination of inner ear fluids (Campo et al., 2001, 1999; Fetoni et al., 2016). Indeed, lipophilic chemicals may transit from the stria vascularis to the sensory hair cells of the organ of Corti through the cellular membranes of the outer sulcus. This potential route of access is supported by studies which demonstrating that non-sensory supporting cells surrounding hair cells, such as Deiters' cells, are more vulnerable to styrene than sensory hair cells (Campo et al., 2001; Chen et al., 2007; Fetoni et al., 2016). As Deiters' cells play a determinant role in potassium re-uptake and recirculation (Hibino and Kurachi, 2006; Spicer and Schulte, 1998), it was suggested that styrene also affects the $\mathrm{K}^{+}$cycle in cochlea (Campo and Maguin, 2007; Chen et al., 2007; Fetoni et al., 2016), although this suggestion was never objectively tested. 
In addition to impairing hearing, solvents have been shown to disrupt balance. Solvents have a negative impact on the sensory-motor integration of postural stability regulation and vestibular pathways (Calabrese et al., 1996; Niklasson et al., 1993; Tham et al., 1990). However, the precise mechanism through which aromatic solvents affect the vestibular system remains elusive. Thus, we still do not know whether the solvents affect the brain structures regulating balance or the vestibular labyrinth localized in the inner ear (Gans et al., 2019).

Both auditory and vestibular sensory organs are localized in the inner ear and share many features. They are both composed of sensory hair cells, which transform the mechanical stimuli into electrical signals. Moreover, they are both filled with a $\mathrm{K}^{+}$-rich fluid, the endolymph, which allows the potassium entry permitting mechano-electrical transduction (MET). The high endolymphatic potassium concentration is the result of ion movements receptor.

To test the vestibular toxicity of solvents, we chose the in vitro "cyst" model initially developed by Gaboyard et al. (2005). The "cyst" is an inflated three-dimensional culture of newborn rat utricle, naturally filled with a high- $\mathrm{K}^{+}$endolymph-like fluid. "Cysts" preserve the key utricular cells types - sensory cells (hair cells) and secretory cells (transitional and dark cells) - and their associated proteins required for $\mathrm{K}^{+}$homeostasis $(\mathrm{MET}$ channels, $\mathrm{Na} / \mathrm{K}-$ ATPase and $\mathrm{Na}-\mathrm{K}-2 \mathrm{Cl}$ co-transporter 1 (NKCC1)). After a few days in a 3D matrix, the utricular explant seals itself to form an endolymphatic compartment filled with high- $\mathrm{K}^{+}$fluid. 
137 Our previous investigation indicated that styrene, an aromatic compound with potent 138 cochleotoxic properties, induced a dose-dependent decrease in $\mathrm{K}^{+}$concentration (Tallandier et 139 al., 2020). Histological and elecrophysiological methods used in this study have shown that 140 endolymphatic $\mathrm{K}^{+}$concentration decreases measurements are more sensitive than histological 141 damages observations to reveal styrene effects. Indeed, a significant decrease of $\mathrm{K}^{+}$ 142 concentration was measured from $0.75 \mathrm{mM}$ of styrene whereas histological damages were 143 observed only after a $1 \mathrm{mM}$-exposure. Therefore, variations in $\mathrm{K}^{+}$concentration in cyst could 144 be considered as an early marker of vestibulotoxicity.

In the present study, the "cyst" model was used to assess the vestibulotoxicity of five aromatic solvents and compare it to that of styrene. All solvents were applied at the same concentration $(0.75 \mathrm{mM})$. Toluene, ethylbenzene and three isomers of xylene were chosen because they are widely used in industrial settings, and have different cochleotoxic properties. Indeed, Gagnaire and Langlais (2005) showed that styrene and ethylbenzene are highly cochleotoxic, that toluene and $p$-xylene are moderately cochleotoxic, and that $m$-xylene and $o$-xylene are not cochleotoxic. The potential vestibulotoxicity of these aromatic solvents was determined by measuring their effects on the endolymphatic $\mathrm{K}^{+}$concentration in cysts, and by histological observations of utricular tissue. This approach allowed us to rank the solvents from most to least vestibulotoxic, and to investigate the relation between cochleotoxicity and vestibulotoxicity.

\section{Materials and methods}

\subsection{Animals}

The animal facility where the rats were housed was fully accredited by the French Ministry of Agriculture (Authorization $\mathrm{N}^{\circ}$ D 54-547-10). Investigators performing animal experiments adhered to the Guide for Care and Use of Laboratory Animals promulgated by the European 
parliament and council (EUROPEAN DIRECTIVE 2010/63/EU, 22 September 2010).

Pregnant Long-Evans female rats were purchased from Janvier Laboratories and were housed in individual cages $\left(1032 \mathrm{~cm}^{2} \times 20 \mathrm{~cm}\right)$ from the $15^{\text {th }}$ day of pregnancy until they gave birth, under a $12 \mathrm{~h}$ light $/ 12 \mathrm{~h}$ dark cycle. Temperature was maintained at $22 \pm 2{ }^{\circ} \mathrm{C}$, the relative humidity was $55 \pm 15 \%$, and food and water were available ad libitum. To monitor weight gain during the pregnancy, animals were weighted at their arrival and just before parturition. Birth was natural, and newborns were used within four days of birth (P0-P4).

\subsection{Cyst culture}

Newborn rats (P0-P4) were decapitated before harvesting the temporal bones and placing them in Leibovitz's L-15 medium. Then utricles were then aseptically removed. The basal surface of the macula was stripped of nervous tissue, taking care to conserve the membrane covering the sensory epithelium. Explants were embedded in $10 \mu 1$ of Matrigel ${ }^{\circledR}$ (Corning, NY, USA) on laminin-coated (10 $\mu \mathrm{g} / \mathrm{ml}$; Sigma-Aldrich, Saint-Louis, MO, U.S.A.) 12-mm diameter glass coverslips. Utricles were positioned so that the basal surface of the sensory epithelium faced the coverslips, and preparations were then incubated at $37^{\circ} \mathrm{C}$ for $30 \mathrm{~min}$ in a $95 \% \mathrm{O}_{2} / 5 \% \mathrm{CO}_{2}$ atmosphere at saturating humidity to solidify the matrix. Embedded utricular explants were then cultivated in Dulbecco's Modified Eagle Medium / Nutrient Mixture F-12 (DMEM-F12, Thermo Fisher Scientific, Waltham, MA, USA) supplemented with $2 \% \mathrm{~N}-2$ (Life Technologies, Carlsbad, California). Explants were maintained at $37{ }^{\circ} \mathrm{C}$ under a humidified $5 \% \mathrm{CO}_{2}$ atmosphere. Half of the culture medium was renewed 3 times per week. After a few days in vitro (DIV), utricular structures sealed themselves, enclosing some fluid. The sealed utricular explant was called a "cyst".

\subsection{Electrophysiological recordings}


Ion-sensitive microelectrodes were used to record the $\mathrm{K}^{+}$concentration in the endolymphatic compartment of "cysts". Borosilicate glass capillaries with filament (1B100F-4; WPI, Sarasota, FL, USA) were melted and pulled using a vertical electrode puller (PUL-100 Microprocessor-controlled micropipette Puller, WPI, Sarasota, FL, USA) and baked at $200{ }^{\circ} \mathrm{C}$ for $2 \mathrm{~h}$. The inside of the microelectrode was silanized with dichlorodimethylsilane vapors (Sigma-Aldrich, Saint-Quentin Fallavier, France) for $5 \mathrm{~min}$ at $100{ }^{\circ} \mathrm{C}$. Microelectrodes were then baked once again for $4 \mathrm{~h}$ at $200{ }^{\circ} \mathrm{C}$ to eliminate all traces of moisture. The microelectrode tip was backfilled with a short column of membrane liquid $\mathrm{K}^{+}$ion exchanger (Potassium Ionophore I - Cocktail B, Sigma-Aldrich, Saint-Quentin Fallavier, France), and the barrel was filled with $150 \mathrm{mM} \mathrm{KCl}$. Microlectrodes with impedances of less than $70 \mathrm{M} \Omega$ or greater than $200 \mathrm{M} \Omega$ were discarded. Microelectrodes with satisfying impedances were connected to the input of a differential electrometer amplifier (HiZ-223 Warner Instruments, Hamden, USA). The electrical circuit was closed when the reference electrode was immersed in the calibrating solutions or culture medium. The electrical signal was monitored using a data-acquisition system (Pulse ${ }^{\circledR}$ software and a 3160-A-022 analyzer, Bruel \& Kjaer, Nærum, Denmark) connected to the amplifier output. Before recording the $\mathrm{K}^{+}$concentration of each sample, the microelectrode was calibrated with $\mathrm{KCl}$ solutions at the following concentrations: $150,100,75,50,20$ and $10 \mathrm{mM}$. Each of these solutions was supplemented with the appropriate amount of $\mathrm{NaCl}$ to provide a final cation concentration of $150 \mathrm{mM}$. Just after the end of exposure, cysts were taken off the vials and placed on the microscope stage to measure the $\mathrm{K}^{+}$concentration. Cyst were recovered with culture medium, which contained a known $\mathrm{K}^{+}$ concentration (about $4 \mathrm{mM} \mathrm{KCl,} \mathrm{DMEM-F12,} \mathrm{Thermo} \mathrm{Fisher} \mathrm{Scientific).} \mathrm{The} \mathrm{medium} \mathrm{was}$ used as a control of recording; just before cyst measuring, the microelectrode tip was immersed in medium to evaluate the $\mathrm{K}^{+}$concentration. The ion-sensitive microelectrode was then inserted into the endolymphatic compartment of the "cyst" under the light microscope. 
After microelectrode insertion, the electrical signal took a few seconds to stabilize. Once exceeded $30 \mathrm{~s}$ (figure 1). The $\mathrm{K}^{+}$concentration was inferred using the calibration curve established previously. Deflated cysts were excluded from the study.

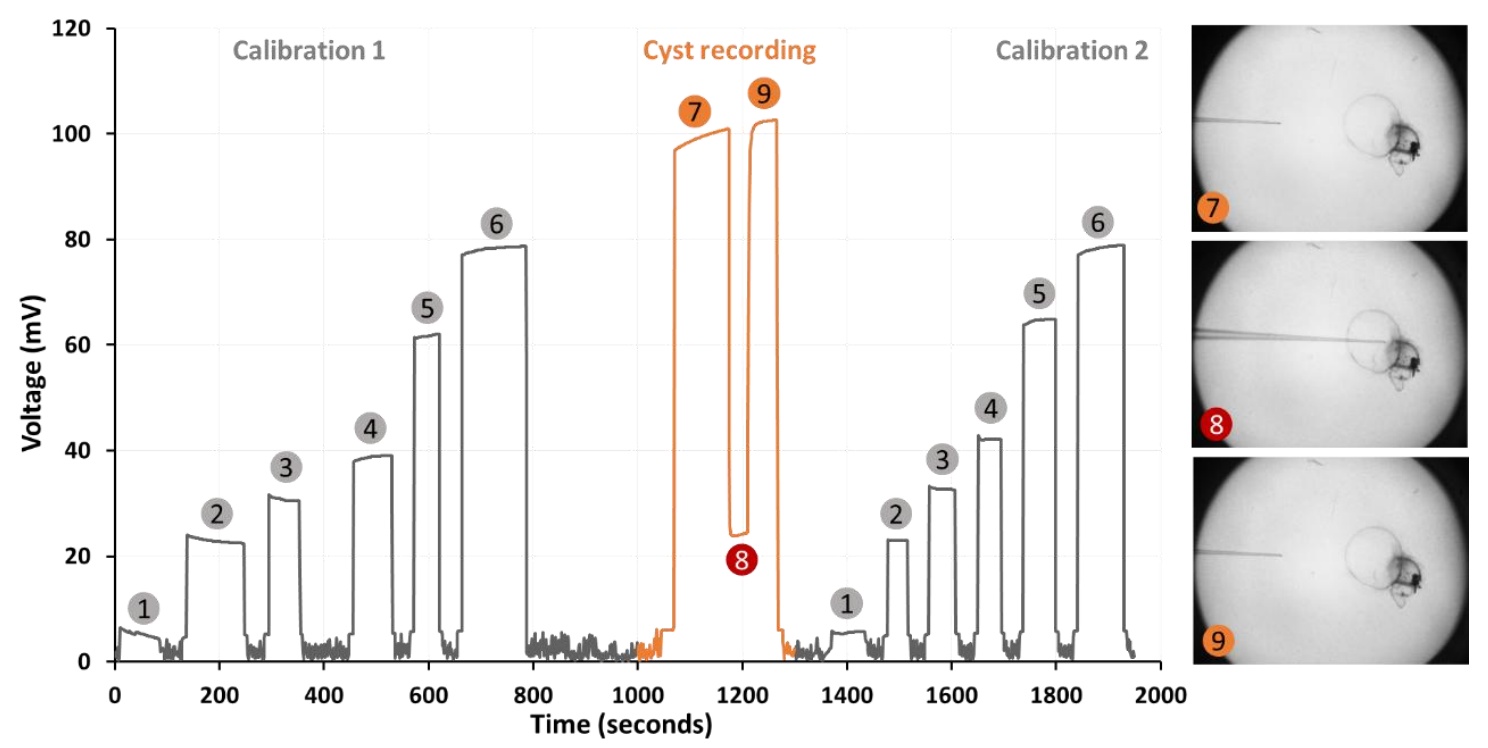

Figure 1. Time course of $\mathrm{K}^{+}$-ion sensitive microelectrode recording before, during and following penetration of cyst. A 7-DIV control cyst was used to represent the measurement progress over time. The y-axis represents the voltage read by the differential amplifier $(\mathrm{mV})$ and the $\mathrm{x}$-axis represents the time (seconds). The values 1 to 6 represent the microelectrode calibration with 6 different $\mathrm{KCl}$ solutions: 150 (1); 100 (2); 75 (3); 50 (4); 20 (5) and $10 \mathrm{mM} \mathrm{(6).} \mathrm{The} \mathrm{voltage} \mathrm{was} \mathrm{recorded} \mathrm{in} \mathrm{medium}$ culture before (7) and after (9) the impalement of the tip of the microelectrode in lumen of cyst (8). The electrical potential change was immediate once the microelectrode tip penetrated inside the lumen of cyst (8). The stabilization of the electrical signal took few seconds and the voltage was rapidly registered. The duration of the cyst measurement never exceeded $30 \mathrm{~s}$. Once the microelectrode was remove from the cyst lumen, the electrical potential back up to initial level (9). The $\mathrm{K}^{+}$concentration was inferred using the calibration curve obtained from data of the 2 calibrations (before and after cyst measurement).

\subsection{Aromatic solvent exposure}

Toluene $(99.9 \%)$ and $o$-xylene $(99.5 \%)$ were obtained from Sigma-Aldrich (Saint-Quentin

Fallavier, France), and ethylbenzene (99.8\%), $p$-xylene (99\%), $m$-xylene ( $\geq 99 \%)$ and styrene

(DMEM-F12, Thermo Fisher Scientific, Waltham, MA, USA) in a volumetric flask to obtain 
tests carried out in a companion publication (Tallandier et al., 2020). The same methode was used to prepare the different stock solutions $(0.25,0.5$ and $0.75 \mathrm{mM})$ for o-xylene, ethylbenzene and styrene. Then, the solvent-enriched medium was supplemented with $\mathrm{N}-2$ $(2 \%, \mathrm{v} / \mathrm{v})$ before pouring into glass headspace vials $(8 \mathrm{ml})$, in which the "cyst" was placed. The vial was immediately sealed with a Teflon-faced butyl rubber septum and an aluminum crimp cap to minimize solvent evaporation. Vials were completely filled to avoid gas-phase solvent stagnation. "Cysts" were cultured in these conditions for $2 \mathrm{~h}$ or $72 \mathrm{~h}$, and $\mathrm{K}^{+}$ concentrations were measured at 7 DIV. Exposures were performed at 7 DIV for the 2-h exposures. For the 72-h exposures, "cysts" were cultured in solvent-enriched medium from the $4^{\text {th }}$ to the $7^{\text {th }}$ DIV. Control "cysts" were placed in vials filled with solvent-free medium for $2 \mathrm{~h}$ or $72 \mathrm{~h}$.

\subsection{Preparation of tissue sections for light microscopy}

Just after $\mathrm{K}^{+}$measurement, "cysts" were immersed in a fixative solution (glutaraldehyde $2.5 \%$ in $0.2 \mathrm{M}$ cacodylate buffer) for $24 \mathrm{~h}$. After rinsing with $0.2 \mathrm{M}$ cacodylate buffer, samples were post-fixed with $1 \%$ osmium tetroxide for $1 \mathrm{~h}$. Samples were dehydrated in graded concentrations of ethanol up to $100 \%$. "Cysts" were then soaked in incremental $50 \%$ / 50\% and $75 \%$ / 25\% resin / propylene oxide solutions before embedding them in pure epoxy resin. After polymerization at $60{ }^{\circ} \mathrm{C}$ for $24 \mathrm{~h}$, transversal semi-thin sections $(2.5 \mu \mathrm{m})$ were cut with a microtome (Leica, UC7) and stained with toluidine blue (Sigma-Aldrich, Saint-Quentin Fallavier, France). Observations were performed under an optical microscope (BX41, Olympus, Tokyo, Japan).

\subsection{Immunohistochemical analysis of cleaved caspase-3}

"Cysts" were fixed in $4 \%$ formaldehyde ( $\mathrm{pH}$ 6.9) for $24 \mathrm{~h}$. Samples were then rinsed in Phosphate-Buffered Saline (PBS) and dehydrated in graded ethanol concentrations up to $100 \%$ before embedding in paraffin. Embedded cysts were cut into $4-\mu \mathrm{m}$ transversal sections 
with a microtome (Microm, HM 34OE). Sections were dipped in xylene to remove paraffin and rehydrated using a decreasing ethanol gradient. Heat-induced antigen retrieval was conducted with $10 \mathrm{mM}$ citrate buffer (pH 6) for $5 \mathrm{~min}$. Endogenous peroxidase activity was blocked with $3 \% \mathrm{H}_{2} \mathrm{O}_{2}$ for $5 \mathrm{~min}$, and non-specific sites were blocked with $10 \%$ of normal goat serum for $1 \mathrm{~h}$ at room temperature. Sections were then incubated with rabbit primary monoclonal antibody directed against cleaved caspase 3 (dilution 1/800, Cell Signaling, MA, USA) overnight at $4{ }^{\circ} \mathrm{C}$. Experimental controls were not exposed to a primary antibody. Sections were then rinsed in TBST-1X and incubated with the peroxidase-containing detection reagent enzyme (SignalStain ${ }^{\circledR}$ Boost Detection Reagent, Cell Signaling) at room temperature for $30 \mathrm{~min}$. Samples were incubated with 3,3'-diaminobenzidine (DAB) to observe specific antibody localization, and counterstained with Mayer Haemalum. Finally, sections were mounted and observed under an optical microscope (BX41, Olympus, Tokyo, Japan).

\subsection{Statistical analysis}

Data were expressed as mean \pm standard error of the mean (SEM). One-way ANOVAs were performed to analyze differences between experimental and control groups. Statistical results were expressed as follows: $\mathrm{F}(\mathrm{dfb}, \mathrm{dfr})=\mathrm{F}-$ ratio; $\mathrm{p}=\mathrm{p}$ value, where $\mathrm{dfb}$ is the number of degrees of freedom between groups, and dfr is the number of residual degrees of freedom. Dunnett's post-hoc tests were used to compare variations between pairs of experimental groups. The threshold for statistical significance was set at $\mathrm{p}=0.05$.

\section{Results}

\subsection{Aromatic solvents have distinct effects on endolymphatic $\mathrm{K}^{+}$concentration}

To assess the effects of different aromatic solvents on $\mathrm{K}^{+}$concentration in the endolymphatic compartment, "cysts" were exposed to the same concentration $(0.75 \mathrm{mM})$ of $o$-xylene, $m$ - 
xylene, $p$-xylene, toluene, ethylbenzene, or styrene for $2 \mathrm{~h}$ or $72 \mathrm{~h}$ (figure 2). In these experiments, the 2 -h solvent exposure had a significant $[F(6,75)=3.285 ; \mathrm{p}<0.01]$ effect on

\section{B 72-h exposure}
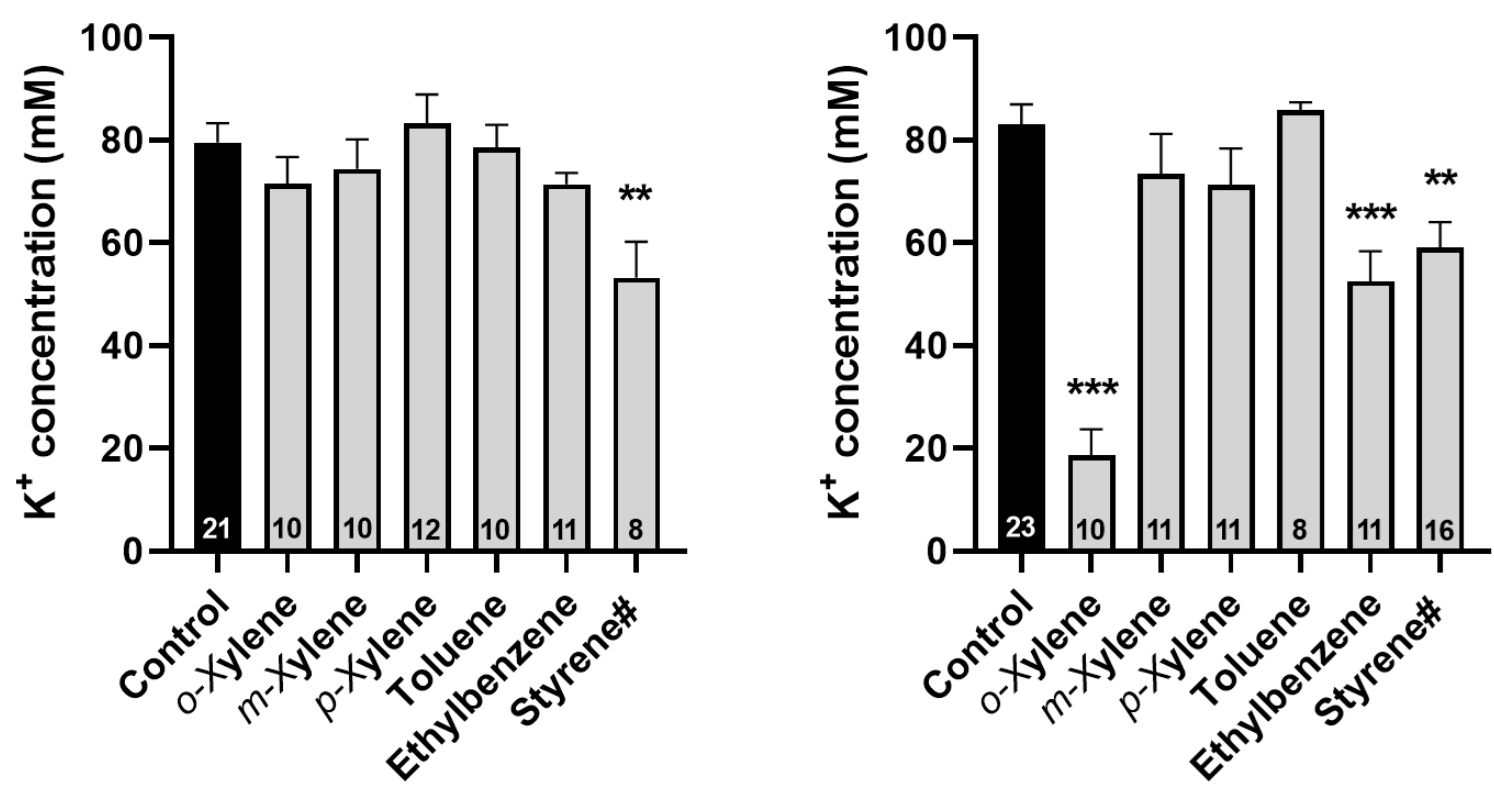

Figure 2. Aromatic solvents alter endolymphatic $\mathbf{K}^{+}$concentrations in "cysts": "Cysts" were 
(B). Control "cysts" were maintained in sealed vials for 2 or $72 \mathrm{~h}$. Each histogram represents the mean \pm SEM, the number corresponds to the number of samples used in each experiment. Asterisks highlight significant differences between solvent-exposed and control data (post-hoc Dunnett: ***p < 0.001). \#: styrene data were previously published in Tallandier et al. (2020). Experiments involving styrene were performed in the same conditions and over the same time range as the other treatments.

“Cysts" were exposed for $72 \mathrm{~h}$ to lower concentrations $(0.25 ; 0.5$ and $0.75 \mathrm{mM})$ of o-xylene, ethylbenzene and styrene (figure 3). A dose-dependent decrease in $\mathrm{K}^{+}$concentration were measured after $o$-xylene $[\mathrm{F}(3,49)=19.02 ; \mathrm{p}<0.001$; figure $3 . A]$, ethylbenzene $[\mathrm{F}(3,49)=$ 5.94; $\mathrm{p}=0.001$; figure 3.B $]$ and styrene $[\mathrm{F}(3,46)=4.38 ; \mathrm{p}=0.008$; figure 3.C $]$ exposure. As observed in figure $2, \mathrm{~K}^{+}$concentration decreased significantly compared to control group for “cysts" exposed to $0.75 \mathrm{mM}$ of $o$-xylene, ethylbenzene or styrene. After exposure to o-xylene and ethylbenzene to $0.5 \mathrm{mM}, \mathrm{K}^{+}$concentration decreased significantly by $40 \%$ (from control level $79.2 \pm 4.1 \mathrm{mM}$ to $47.6 \pm 11.3 \mathrm{mM} ; \mathrm{p}=0.002$; figure $3 . A$ ) and $28 \%$ (from control level $79.2 \pm 4.1 \mathrm{mM}$ to $56.9 \pm 8.1 \mathrm{mM} ; \mathrm{p}=0.023$; figure 3.B), respectively. Exposure to $0.5 \mathrm{mM}$ of styrene lead a decreasing trend of $\mathrm{K}^{+}$concentration (from control level $80.5 \pm 4.4 \mathrm{mM}$ to 65.0 $\pm 4.3 \mathrm{mM} ; \mathrm{p}=0.068$; figure 3.C).
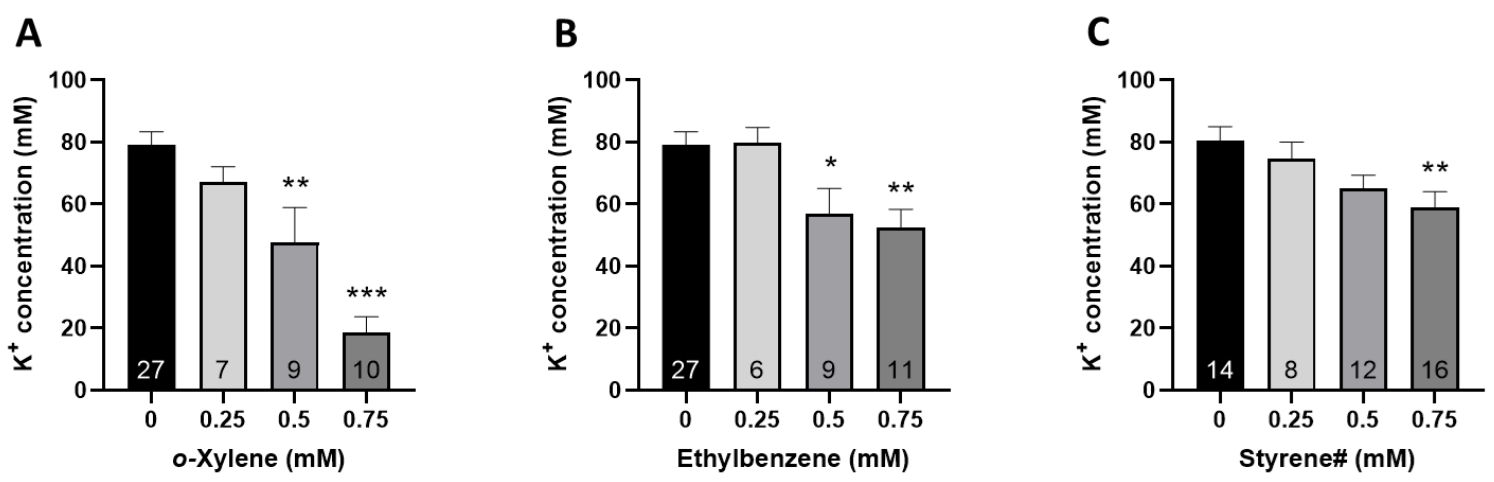

Figure 3. $o$-Xylene, ethylbenzene and styrene cause a dose-dependent decrease of endolymphatic $\mathrm{K}^{+}$concentration in "cysts": "Cysts" were obtained from newborn rats (P2-P4) and $\mathrm{K}^{+}$ concentrations were measured at 7 DIV. Utricle explants were exposed to varying concentrations $(0.25 ; 0.5$ and $0.75 \mathrm{mM})$ to $o$-xylene (A), ethylbenzene (B) or styrene (C) for $72 \mathrm{~h}$. Control samples were maintained in sealed vials without solvents for $72 \mathrm{~h}$. Each histogram represents the mean \pm SEM and the number of samples used in each experiment is indicated at the bottom of each bar of the histogram. Asterisks highlight significant differences between solvent-exposed and control data (posthoc Dunnett: $* \mathrm{p}<0.05 ; * * \mathrm{p}<0.01$ and $* * * \mathrm{p}<0.001)$. \#: styrene data were previously published in 
Tallandier et al. (2020). Experiments involving styrene were performed in the same conditions and over the same time range as the other treatments.

\subsection{Only $o$-xylene and styrene induce histological defects}

The gross morphologies of control 7-DIV cysts and cysts exposed to aromatic solvents $(0.75 \mathrm{mM})$ for $72 \mathrm{~h}$ were observed under light microscopy (figures 4 and 5$)$. In control samples, the sensory epithelium displayed healthy-looking type I and II hair cells, with an intact cell membrane and ciliary bundle on their apical surface, as well as a normal nucleus and cytoplasm. Supporting cells were intercalated between hair cells and their nucleus was localized at the basal surface. The secretory area, composed of cuboidal dark cells and transitional cells, was characterized by darker cytoplasms compared to hair cells when stained with toluidine blue. Connective tissue could be observed under both sensory and secretory epithelia (figure 4 et 5).

“Cysts" exposed to $0.75 \mathrm{mM}$ toluene, $m$-xylene and $p$-xylene displayed normal cells in both epithelia and connective tissue (figure 4). Histological features were identical to untreated "cysts". Even though "cysts" exposed to $0.75 \mathrm{mM}$ ethylbenzene for $72 \mathrm{~h}$ displayed a significant drop in $\mathrm{K}^{+}$concentration (figure 2), no sign of cellular stress was observed in these samples. As reported in Tallandier et al. (2020), exposure to $0.75 \mathrm{mM}$ styrene for $72 \mathrm{~h}$ provoked the formation of cytoplasmic vacuoles in all epithelial cell types, but no other obvious features of cell injury were noted in these conditions. Conversely, numerous pathological features, such as swollen and condensed nuclei, low-density cytoplasm, and cellular extrusions through the cuticular plate were observed in histological sections of "cysts" exposed to $o$-xylene. These features indicate damage to cells in both sensory and 
348 secretory areas. Despite this damage to both the sensory and the secretory epithelium, 349 stereocilia were still present (figure 5).

350 Apoptotic processes were studied by the means of the immunochemical staining of cleaved 351 caspase-3 on paraffin sections of cysts exposed to the different solvents for $72 \mathrm{~h}$. Whatever 352 the solvent considered, sections of exposed cysts revealed no positive staining (data not 353 shown), suggesting that the majority of cell death occurred by a non-apoptotic mechanism. 


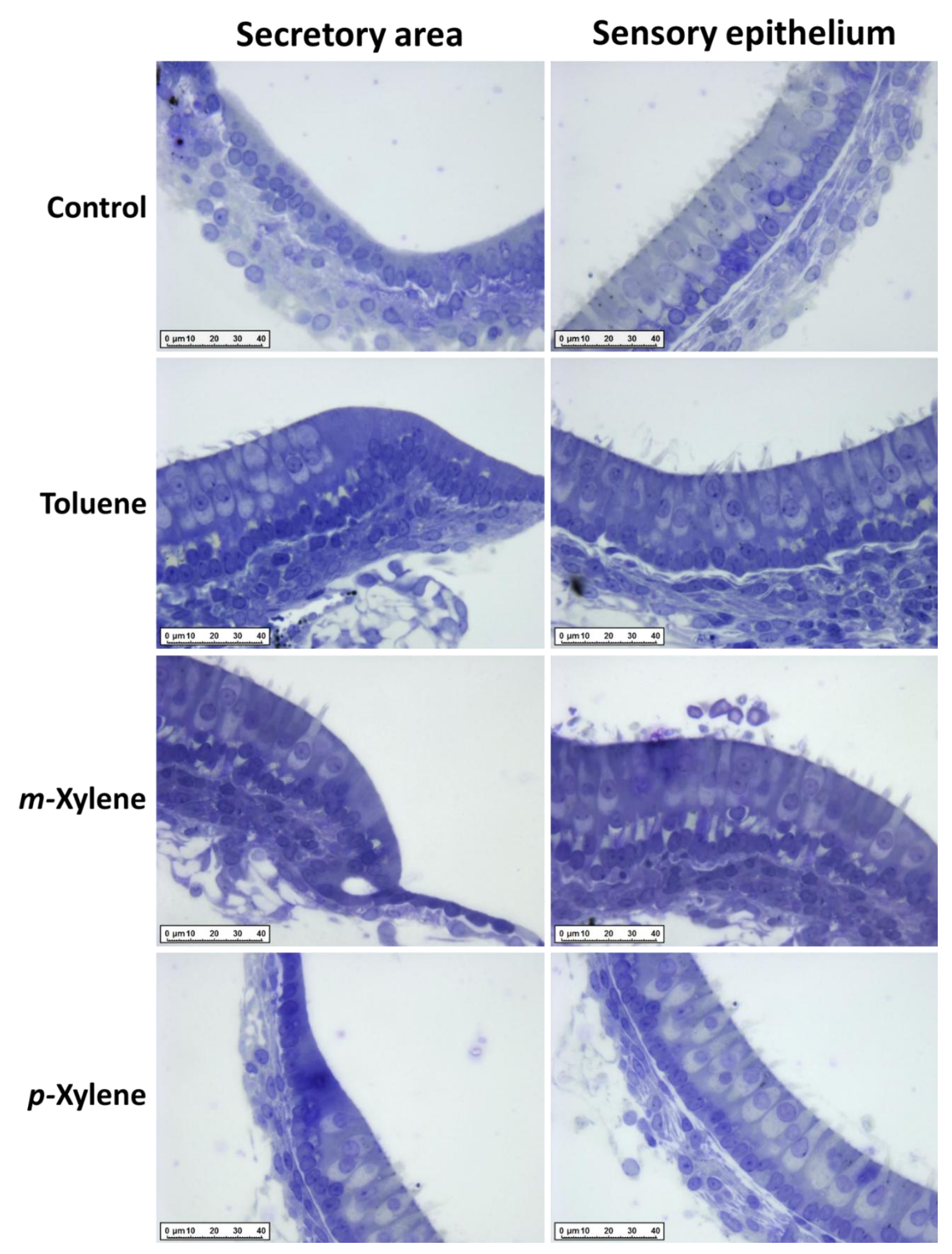

Figure 4. Lack of histological impact on "cysts" exposed to toluene, $m$-xylene, or $p$-xylene for 72 h. "Cysts" (7 DIV) obtained from P2-P4 newborn rats were observed under a light microscope after 72-h exposure to toluene, $m$-xylene, or $p$-xylene at $0.75 \mathrm{mM}$. Left panels show part of the secretory area, whereas right panels show part of the sensory epithelium. No distinguishing histopathological features were observed after exposure to toluene, $m$-xylene, or $p$-xylene exposure. Scale bar $=$ $40 \mu \mathrm{m}$. 


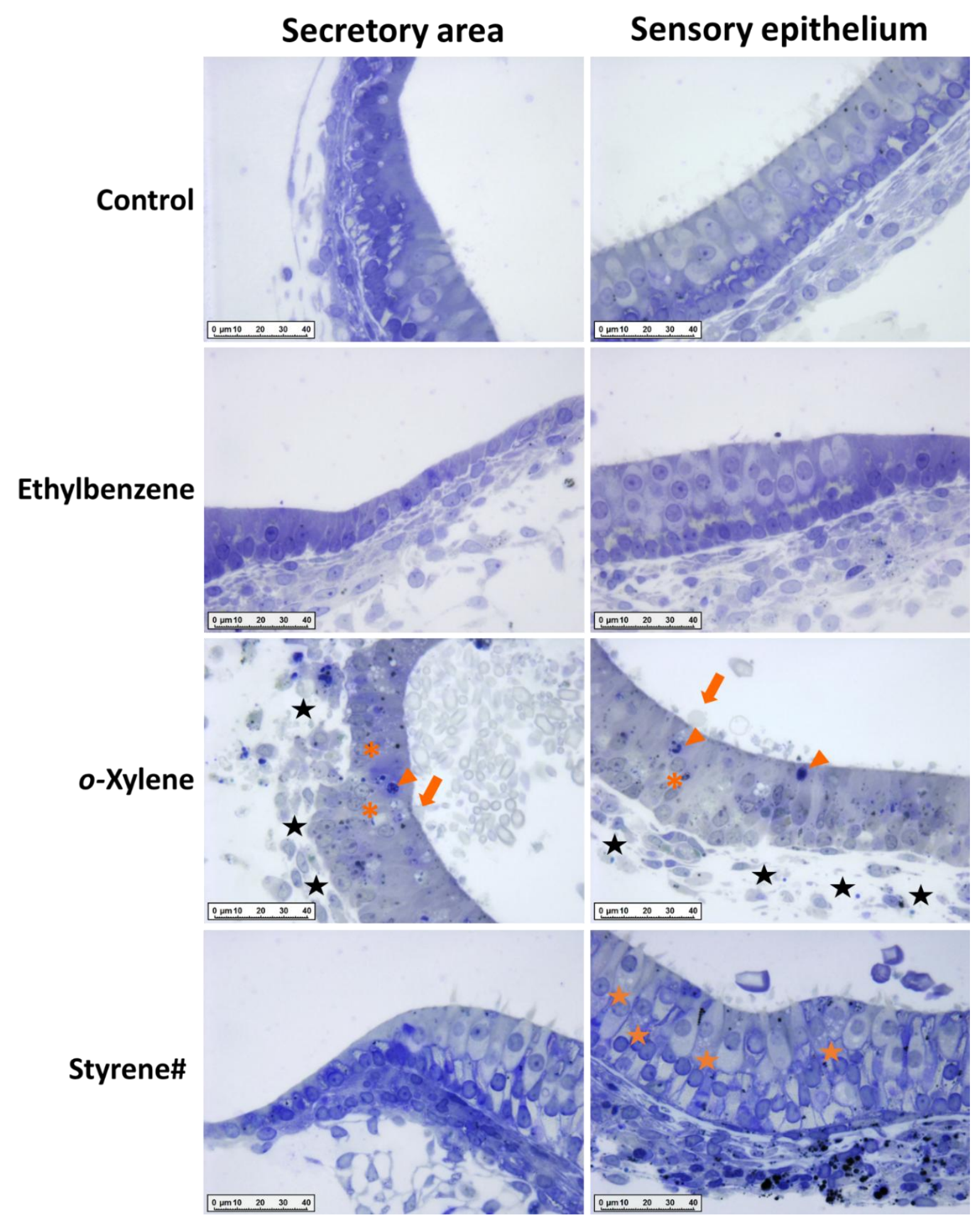

Figure 5. Deleterious histological impact of $72 \mathrm{~h}$ exposure to $o$-xylene and styrene, but not ethylbenzene on "cysts". Cysts (7 DIV) obtained from P2-P4 newborn rats were observed under light microscopy after 72-h exposure to ethylbenzene, $o$-xylene or styrene at $0.75 \mathrm{mM}$. Images of cysts exposed to styrene (\#) for $72 \mathrm{~h}$ were previously published in Tallandier et al. (2020). Left panels display part of the secretory area, whereas right panels show part of the sensory epithelium. Major damage (swollen and condensed nuclei, low-density cytoplasms and cellular extrusions) was observed in "cysts" exposed to $o$-xylene; styrene-exposed "cysts" contained cytoplasmic vacuoles but no other 
visible cellular damage. Extrusions are indicated by arrows, condensed nuclei by arrowheads, swollen nuclei by asterisks, cytoplasmic vacuoles by orange stars, and damaged connective tissue by black stars. Scale bar $=40 \mu \mathrm{m}$.

\section{Discussion}

This study compared the vestibulotoxic effects of six aromatic solvents - chosen for their well-known cochleotoxic properties - using an in vitro model (Bartolami et al., 2011; Gaboyard et al., 2005; Gagnaire and Langlais, 2005). The "cyst" model can be used to assess both functional and morphological consequences of exposure to aromatic solvents on the vestibular receptor. Tests involved measuring variations in the endolymphatic $\mathrm{K}^{+}$ concentration using an electrochemical technique, and performing histological analyses of the vestibular epithelium.

To evaluate and compare the vestibulotoxic potential of aromatic solvents, "cysts" were exposed to the same concentration $(0.75 \mathrm{mM})$ of styrene, ethylbenzene, toluene, $p$ xylene, $m$-xylene, or $o$-xylene for either $2 \mathrm{~h}$ or $72 \mathrm{~h}$. The exposure durations were initially chosen as they distinguished pharmacological and cytotoxic effects induced by styrene (Tallandier et al., 2020). The concentration was chosen because this previous study showed that both 2-h and 72-h exposures to $0.75 \mathrm{mM}$ styrene caused a decrease of $\mathrm{K}^{+}$concentration with no sign of cell death in secretory or sensory epithelia. However, cytoplasmic vacuoles were visible in secretory and sensory cells after just $2 \mathrm{~h}$ exposure to styrene $(0.75 \mathrm{mM})$. Even if vacuolization is not a sign of dying cells per se, it can be an early symptom of cellular stress caused by the action of a cytotoxic inducer (Shubin et al., 2016), and might thus ultimately lead to cell death. With regard to cell death, the results presented here showed that death mainly occurs by a non-apoptotic pathway, as no immuno-histological staining of cleaved caspase-3 was detected in "cysts" for any of the solvents studied. This result is in accordance with those obtained by Diodovich et al. (2006, 2004), who exposed human hepatocytes and human cord blood cells to styrene at comparable concentrations and for similar durations. 
They reported that exposure to styrene at $0.5,0.8$ or $1 \mathrm{mM}$ for $24 \mathrm{~h}$ or $72 \mathrm{~h}$ did not induce apoptotic pathways, but mainly elicited necrosis.

In addition, numerous studies have demonstrated that aromatic solvents can modulate ion channels, such as the acetylcholine and N-methyl-D-aspartate (NMDA) receptor or the $\mathrm{Na} / \mathrm{K}$ ATPase (Bale et al., 2005; Calderón-Guzmán et al., 2005; Cruz et al., 2000; Vaalavirta and Tähti, 1995a). The variations of $\mathrm{K}^{+}$concentration measured after 2-h styrene exposure might therefore be the result of both a pharmacological modulation of ion channels and a toxic effect on other targets.

Unlike styrene, the other solvents tested in the present study did not induce changes in the $\mathrm{K}^{+}$concentration after $2 \mathrm{~h}$ exposure. However, we observed $78 \%$ and $37 \%$ decreases in the $\mathrm{K}^{+}$ concentration for $o$-xylene and ethylbenzene, respectively, after $72 \mathrm{~h}$ exposure to $0.75 \mathrm{mM}$. For comparison, exposure to styrene for $72 \mathrm{~h}$ resulted in a $28 \%$ drop in $\mathrm{K}^{+}$concentration. In contrast, the other three aromatic solvents - toluene, $p$-xylene and $m$-xylene - had no measurable effect on the $\mathrm{K}^{+}$concentration even after $72 \mathrm{~h}$ (figure 2). A dose-dependent decrease of endolymphatic $\mathrm{K}^{+}$concentration was measured in "cysts" exposed to $o$-xylene, ethylbenzene and styrene for $72 \mathrm{~h}$ (figure 3). Our findings indicate that $o$-xylene and ethylbenzene decrease $\mathrm{K}^{+}$concentration from a solvent concentration as low as $0.5 \mathrm{mM}$ after 72-h exposure. However, the decrease of $\mathrm{K}^{+}$level was significant only from 0.75 of styrene. Therefore, these data allow considering that $0.75 \mathrm{mM}$ is the threshold concentration to have a significant impact on the $\mathrm{K}+$ concentration in "cysts".

The histological results presented in figures 4 and 5 show that only the solvent with the strongest effect on $\mathrm{K}^{+}$concentrations, $o$-xylene, induced obvious cell death in the vestibular secretory and sensory epithelia. Pathological features included low-density cytoplasm, cellular extrusions from cuticular plate, and morphological changes to the nucleus (condensed and swollen). These features are most likely indicative of irreversible damage. 
Comparison between electrophysiological and histological data suggests that $\mathrm{K}^{+}$concentration

422 (after $72 \mathrm{~h}$ exposure) is a more sensitive endpoint than tissue histology when assessing the

423

424

425 toxicity of aromatic solvents. Indeed, no sign of histological injury was visible after exposure to ethylbenzene, and only discreet signs were detected after exposure to styrene for $72 \mathrm{~h}$, while these solvents decreased the $\mathrm{K}^{+}$concentrations by 37 and $28 \%$, respectively. Interestingly, in Tallandier et al. (2020), “cysts" exposed to $1 \mathrm{mM}$ styrene displayed the same histological damage and impact on $\mathrm{K}^{+}$levels as those exposed to $0.75 \mathrm{mM} o$-xylene here, with an exposure duration of $72 \mathrm{~h}$ in both cases. In summary, the "cyst" model provides a graded and selective response reflecting the vestibulotoxicity of aromatic solvents.

Thus, the $\mathrm{K}^{+}$measurements in "cysts" suggest that half of the six solvents tested could have vestibulotoxic properties. If we classify these aromatic solvents according to their vestibulotoxic potency, the following ranking is obtained: $o$-xylene is highly vestibulotoxic, styrene and ethylbenzene have moderate vestibulotoxic effects, and finally toluene, $p$-xylene and $m$-xylene are not vestibulotoxic (table 1).

As for cochleotoxicity, vestibulotoxicity is closely linked to the chemical formula of the aromatic solvent considered. However, based on our data we were unable to infer a possible mechanism. Nevertheless, we can attempt to relate the toxic effect to chemical properties of the different solvent species tested here. Aromatic solvents have been demonstrated to decrease $\mathrm{Na} / \mathrm{K}$-ATPase activities in primary cultures of rat astrocytes in a dose-dependent manner, and this effect was linked to their lipophilic properties (Vaalavirta and Tähti, 1995b). However, the data presented here do not support this statement. Indeed, solvents with similar octanol/water partition coefficients $\left(\log \mathrm{K}_{\mathrm{ow}}\right)$ had very different effects on $\mathrm{K}^{+}$concentrations. For instance, $m$-xylene and $p$-xylene did not affect $\mathrm{K}^{+}$concentration, whereas $o$-xylene and ethylbenzene strongly reduced it (table 1). Consequently, the lipophilic properties of the solvents cannot explain the extent of their vestibulotoxic effects. 
An alternative possibility is that differences in the chemical structure of solvents, and in

447 particular steric hindrance, could explain the differences in toxicity observed. For instance,

448 the number of carbons on the side chain of the aromatic ring could play a role in the

449

450

451

452

453

454

455

456

457

458

459

460

461

462

463

464

465 vestibulotoxic process. Indeed, ethylbenzene and styrene each have two carbons on their side chains, and generated significant variations in the $\mathrm{K}^{+}$concentration in the endolymph. To further study the link between the chemical structure of the solvent studied and its toxicity in the "cyst" model, it would be interesting to test other molecules, for example molecules with more carbon atoms in their side chains, such as with studies modelled on the comparison made by Gagnaire and Langlais (2005) in their in vivo study of the cochleotoxicity of 21 aromatic solvents.

Furthermore, with regard to the xylene isomers, the position of the two-methyl groups on the benzene ring appears to play a determinant role. The in vivo study of the cochleotoxicity of xylenes led to similar structure-function hypotheses (Gagnaire et al., 2001; 2007; Gagnaire and Langlais, 2005; Maguin et al., 2006). However, the results of these previous studies showed that $p$-xylene is more cochleotoxic than the $o$-xylene, which contrasts with the in vitro results presented here. Obviously, this apparent discrepancy could be explained by multiple factors, and it is inherently difficult to draw parallels between in vitro vestibulotoxicity and in vivo cochleotoxicity.

Similarly, studies of the ototoxicity of aminoglycosides, which are hydrophilic compounds, also noted discrepancies between vestibulotoxicity and cochleotoxicity (Freeman et al., 2001; Kitasato et al., 1990; Nakashima et al., 2000). Thus, susceptibility would rather depend on the selective sensitivity of cochlear and vestibular cells, than on the route of intoxication within the inner ear. 
Table 1. Comparison between cochleotoxic and vestibulotoxic effects for each aromatic solvent

\begin{tabular}{|c|c|c|c|c|c|}
\hline $\begin{array}{l}\text { Aromatic } \\
\text { solvent }\end{array}$ & $\begin{array}{l}\text { Vestibulotoxicity } \\
\text { (K } \mathbf{K}^{+} \text {variation) }\end{array}$ & $\begin{array}{l}\text { Vestibulotoxicity } \\
\text { (cellular damage) }\end{array}$ & $\begin{array}{l}\text { Cochleotoxicity } \\
\text { (hair cell loss) }\end{array}$ & $\begin{array}{l}\text { Lipophilicity } \\
\quad\left(\log K_{o w}\right)\end{array}$ & Structure \\
\hline$o$-xylene & ++ & ++ & - & 3.12 & \\
\hline styrene & + & + & ++ & 2.95 & \\
\hline ethylbenzene & + & - & ++ & 3.15 & \\
\hline toluene & - & - & + & 2.73 & \\
\hline$p$-xylene & - & - & + & 3.15 & \\
\hline$m$-xylene & - & - & - & 3.2 & \\
\hline
\end{tabular}

474

Structure and lipophilicity (octanol / water partition coefficient) of each solvent tested in this study. Cochleotoxic properties of each solvent were taken from Gagnaire and Langlais (2005), and vestibulotoxic effects $\left(\mathrm{K}^{+}\right.$variation and cellular damage) correspond to results from the present study. The strength of the effects are classified as follows: "++" for strongly, "+" for moderate or "_" for non-active.

\section{Conclusion}

To our knowledge, this is the first study to focus on the impact of aromatic solvents on the vestibular receptor. Indeed, previous studies examining the effects of solvents on the vestibular system could not discriminate between central and peripheral effects. "Cysts" can be used to measure the endolymphatic $\mathrm{K}^{+}$concentration, which reflects the functionality of vestibular cells. In addition, variations in $\mathrm{K}^{+}$concentrations appear to be an earlier indicator than histological damage. Among the aromatic solvents tested in this study, the "cyst" model 
ranked the strength of the vestibulotoxicity as follows: $o$-xylene appears to be the most vestibulotoxic, whereas styrene and ethylbenzene are moderately vestibulotoxic, and toluene, $p$-xylene and $m$-xylene have no effect. It seems that molecular structure determines vestibulotoxicity. These first results encourage us to extend our study to other solvents with more complex structures, to establish the link between chemical structure and toxicity, and to undertake chronic in vivo studies to validate the predictive value of the "cyst" model.

\section{Acknowledgements}

The authors would like to thank Laurine Douteau and Marie-Joseph Décret for their help with animal husbandry, Aurélie Remy for statistical analysis and Thomas Venet for his invaluable knowledge on the acquisition of electrophysiological data.

\section{References}

Bale, A.S., Meacham, C.A., Benignus, V.A., Bushnell, P.J., Shafer, T.J., 2005. Volatile organic compounds inhibit human and rat neuronal nicotinic acetylcholine receptors expressed in Xenopus oocytes. Toxicol. Appl. Pharmacol. 205, 77-88. https://doi.org/10.1016/j.taap.2004.09.011

Bartolami, S., Gaboyard, S., Quentin, J., Travo, C., Cavalier, M., Barhanin, J., Chabbert, C., 2011. Critical Roles of Transitional Cells and Na/K-ATPase in the Formation of Vestibular Endolymph. Journal of Neuroscience 31, 16541-16549. https://doi.org/10.1523/JNEUROSCI.2430-11.2011

Calabrese, G., Martini, A., Sessa, G., Cellini, M., Bartolucci, G.B., Marcuzzo, G., De Rosa, E., 1996. Otoneurological study in workers exposed to styrene in the fiberglass industry. Int Arch Occup Environ Health 68, 219-223.

Calderón-Guzmán, D., Hernández-Islas, J.L., Espítia Vázquez, I.R., Barragán-Mejía, G., HernándezGarcía, E., Del Angel, D.S., Juárez-Olguín, H., 2005. Effect of toluene and cresols on $\mathrm{Na+,K+-}$ ATPase, and serotonin in rat brain. Regul. Toxicol. Pharmacol. 41, 1-5. https://doi.org/10.1016/j.yrtph.2004.09.005

Campo, P., Lataye, R., Loquet, G., Bonnet, P., 2001. Styrene-induced hearing loss: a membrane insult. Hear. Res. 154, 170-180.

Campo, P., Loquet, G., Blachère, V., Roure, M., 1999. Toluene and styrene intoxication route in the rat cochlea. Neurotoxicol Teratol 21, 427-434.

Campo, P., Maguin, K., 2007. Solvent-induced hearing loss: mechanisms and prevention strategy. Int J Occup Med Environ Health 20, 265-270. https://doi.org/10.2478/v10001-007-0031-3

Cappaert, N.L., Klis, S.F., Baretta, A.B., Muijser, H., Smoorenburg, G.F., 2000. Ethyl benzene-induced ototoxicity in rats: a dose-dependent mid-frequency hearing loss. J. Assoc. Res. Otolaryngol. 1, 292-299. https://doi.org/10.1007/s101620010050

Chen, G.-D., Chi, L.-H., Kostyniak, P.J., Henderson, D., 2007. Styrene induced alterations in biomarkers of exposure and effects in the cochlea: mechanisms of hearing loss. Toxicol. Sci. 98, 167-177. https://doi.org/10.1093/toxsci/kfm078 
Ciuman, R.R., 2009. Stria vascularis and vestibular dark cells: characterisation of main structures responsible for inner-ear homeostasis, and their pathophysiological relations. The Journal of Laryngology \& Otology 123, 151. https://doi.org/10.1017/S0022215108002624

Cruz, S.L., Balster, R.L., Woodward, J.J., 2000. Effects of volatile solvents on recombinant N-methyl-Daspartate receptors expressed in Xenopus oocytes. Br. J. Pharmacol. 131, 1303-1308. https://doi.org/10.1038/sj.bjp.0703666

Dick, F.D., 2006. Solvent neurotoxicity. Occup Environ Med 63, 221-226, 179. https://doi.org/10.1136/oem.2005.022400

Diodovich, C., Bianchi, M.G., Bowe, G., Acquati, F., Taramelli, R., Parent-Massin, D., Gribaldo, L., 2004. Response of human cord blood cells to styrene exposure: evaluation of its effects on apoptosis and gene expression by genomic technology. Toxicology 200, 145-157. https://doi.org/10.1016/j.tox.2004.03.021

Diodovich, C., Urani, C., Maurici, D., Malerba, I., Melchioretto, P., Orlandi, M., Zoia, L., Campi, V., Carfi', M., Pellizzer, C., Gribaldo, L., 2006. Modulation of different stress pathways after styrene and styrene-7,8-oxide exposure in HepG2 cell line and normal human hepatocytes. J Appl Toxicol 26, 317-325. https://doi.org/10.1002/jat.1142

Fetoni, A.R., Rolesi, R., Paciello, F., Eramo, S.L.M., Grassi, C., Troiani, D., Paludetti, G., 2016. Styrene enhances the noise induced oxidative stress in the cochlea and affects differently mechanosensory and supporting cells. Free Radic. Biol. Med. 101, 211-225. https://doi.org/10.1016/j.freeradbiomed.2016.10.014

Freeman, S., Priner, R., Elidan, J., Sohmer, H., 2001. Objective method for differentiating between drug-induced vestibulotoxicity and cochleotoxicity. Otol. Neurotol. 22, 70-75. https://doi.org/10.1097/00129492-200101000-00014

Gaboyard, S., Chabbert, C., Travo, C., Bancel, F., Lehouelleur, J., Yamauchi, D., Marcus, D.C., Sans, A., 2005. Three-dimensional culture of newborn rat utricle using an extracellular matrix promotes formation of a cyst. Neuroscience 133, 253-265. https://doi.org/10.1016/j.neuroscience.2005.02.011

Gagnaire, F., Langlais, C., 2005. Relative ototoxicity of 21 aromatic solvents. Archives of Toxicology 79, 346-354. https://doi.org/10.1007/s00204-004-0636-2

Gagnaire, François, Langlais, C., Grossmann, S., Wild, P., 2007. Ototoxicity in rats exposed to ethylbenzene and to two technical xylene vapours for 13 weeks. Arch. Toxicol. 81, 127-143. https://doi.org/10.1007/s00204-006-0124-y

Gagnaire, F., Marignac, B., Blachère, V., Grossmann, S., Langlais, C., 2007. The role of toxicokinetics in xylene-induced ototoxicity in the rat and guinea pig. Toxicology 231, 147-158. https://doi.org/10.1016/j.tox.2006.11.075

Gagnaire, F., Marignac, B., Langlais, C., Bonnet, P., 2001. Ototoxicity in rats exposed to ortho-, metaand para-xylene vapours for 13 weeks. Pharmacol. Toxicol. 89, 6-14. https://doi.org/10.1034/j.1600-0773.2001.d01-129.x

Gans, R.E., Rauterkus, G., Research Associate 1, 2019. Vestibular Toxicity: Causes, Evaluation Protocols, Intervention, and Management. Semin Hear 40, 144-153. https://doi.org/10.1055/s-0039-1684043

Hibino, H., Kurachi, Y., 2006. Molecular and Physiological Bases of the $\mathrm{K}^{+}$Circulation in the Mammalian Inner Ear. Physiology 21, 336-345. https://doi.org/10.1152/physiol.00023.2006

Hibino, H., Nin, F., Tsuzuki, C., Kurachi, Y., 2010. How is the highly positive endocochlear potential formed? The specific architecture of the stria vascularis and the roles of the ion-transport apparatus. Pflugers Arch. 459, 521-533. https://doi.org/10.1007/s00424-009-0754-z

Hodgkinson, L., Prasher, D., 2006. Effects of industrial solvents on hearing and balance: a review. Noise Health 8, 114-133.

Kitasato, I., Yokota, M., Inouye, S., Igarashi, M., 1990. Comparative ototoxicity of ribostamycin, dactimicin, dibekacin, kanamycin, amikacin, tobramycin, gentamicin, sisomicin and netilmicin in the inner ear of guinea pigs. Chemotherapy 36, 155-168.

https://doi.org/10.1159/000238762 
Lang, F., Vallon, V., Knipper, M., Wangemann, P., 2007. Functional significance of channels and transporters expressed in the inner ear and kidney. American Journal of Physiology-Cell Physiology 293, C1187-C1208. https://doi.org/10.1152/ajpcell.00024.2007

Loquet, G., Campo, P., Lataye, R., 1999. Comparison of toluene-induced and styrene-induced hearing losses. Neurotoxicol Teratol 21, 689-697.

Maguin, K., Lataye, R., Campo, P., Cossec, B., Burgart, M., Waniusiow, D., 2006. Ototoxicity of the three xylene isomers in the rat. Neurotoxicol Teratol 28, 648-656. https://doi.org/10.1016/j.ntt.2006.08.007

Nakashima, T., Teranishi, M., Hibi, T., Kobayashi, M., Umemura, M., 2000. Vestibular and cochlear toxicity of aminoglycosides--a review. Acta Otolaryngol. 120, 904-911. https://doi.org/10.1080/00016480050218627

Niklasson, M., Tham, R., Larsby, B., Eriksson, B., 1993. Effects of toluene, styrene, trichloroethylene, and trichloroethane on the vestibulo-and opto-oculo motor system in rats. Neurotoxicol Teratol 15, 327-334.

Shubin, A.V., Demidyuk, I.V., Komissarov, A.A., Rafieva, L.M., Kostrov, S.V., 2016. Cytoplasmic vacuolization in cell death and survival. Oncotarget 7, 55863-55889. https://doi.org/10.18632/oncotarget.10150

Spicer, S.S., Schulte, B.A., 1998. Evidence for a medial K+ recycling pathway from inner hair cells. Hear. Res. 118, 1-12.

Sułkowski, W.J., Kowalska, S., Matyja, W., Guzek, W., Wesołowski, W., Szymczak, W., Kostrzewski, P., 2002. Effects of occupational exposure to a mixture of solvents on the inner ear: a field study. Int J Occup Med Environ Health 15, 247-256.

Tallandier, V., Merlen, L., Boucard, S., Thomas, A., Venet, T., Chalansonnet, M., Gauchard, G., Campo, P., Pouyatos, B., 2020. Styrene alters potassium endolymphatic concentration in a model of cultured utricle explants. Toxicology in Vitro 104915. https://doi.org/10.1016/j.tiv.2020.104915

Tham, R., Larsby, B., Eriksson, B., Niklasson, M., 1990. The effect of toluene on the vestibulo- and opto-oculomotor system in rats, pretreated with GABAergic drugs. Neurotoxicol Teratol 12, 307-311. https://doi.org/10.1016/0892-0362(90)90048-h

Unlu, I., Kesici, G.G., Basturk, A., Kos, M., Yılmaz, O.H., 2014. A comparison of the effects of solvent and noise exposure on hearing, together and separately. Noise Health 16, 410-415. https://doi.org/10.4103/1463-1741.144422

Vaalavirta, L., Tähti, H., 1995a. Effects of selected organic solvents on the astrocyte membrane ATPase in vitro. Clin. Exp. Pharmacol. Physiol. 22, 293-294. https://doi.org/10.1111/j.14401681.1995.tb01999.x

Vaalavirta, L., Tähti, H., 1995b. Astrocyte membrane $\mathrm{Na+}, \mathrm{K}(+)$-ATPase and $\mathrm{Mg}(2+)$-ATPase as targets of organic solvent impact. Life Sci. 57, 2223-2230. https://doi.org/10.1016/00243205(95)02214-4

Vyskocil, A., Truchon, G., Leroux, T., Lemay, F., Gendron, M., Gagnon, F., Majidi, N.E., Boudjerida, A., Lim, S., Emond, C., Viau, C., 2012. A weight of evidence approach for the assessment of the ototoxic potential of industrial chemicals. Toxicol Ind Health 28, 796-819. https://doi.org/10.1177/0748233711425067 